\title{
The Information Technology and Business Requirement Evolution
}

\author{
Dr. Aurora Binjaku \\ Prof. Assoc. Dr. Tamara Luarasi \\ Prof. Assoc. Dr. Hysen Binjaku
}

aurora.binjaku@digitalb.tv, tamara.luarasi@uet.edu.al, hysen.binjaku@uet.edu.al

\section{Doi:10.5901/ajis.2013.v2n3p55}

\section{Abstract}

In our economy there is a high variety of business models and activities. For being competitive, companies have the need to compile diverse financial reporting in order to provide correct and in time information. Various activities get along with a variety of financial reporting based on the financial activity data. High demand for the financial reporting variety has affected the development of software and programming technology that facilitate the reports generation. Nowadays, keeping electronic data is inseparable from everyday work process. This study makes evident that technology development takes forward the economic thinking. Finance's demand to IT specialists for more detailed information and how the economic thinking is principal for the information technology development are the core materials of the study. To achieve the objective a case study is taken as an example. We take in consideration the experience of an Albanian company that operates in the pay television field. Actually the company has professional software that can manage the sales data in various reports. The database creates the possibility to filter and process the information as the demand leads. But, there is still the need to process the data in other programs to have a complex reporting on the deferred revenues. This fact takes us to a deeper thinking and we analyze the interaction between finance and IT specialist. Analyses give us the possibility to come to some conclusions at the end.

Keywords: financial data processing, financial reporting, Information technology, Business and Information Technology interaction, Google Cloud SQL.

\section{Introduction}

In our economy there is a high variety of business models and activities. For being competitive, companies have the need to compile diverse financial reports so they can provide correct and in real time information. High demand for financial reporting has affected the development of software and information technology that facilitate the data processing activity. Nowadays, recording electronic data is inseparable from everyday working process.

Companies that are quoted in the stock market are obliged to disclose their financial reports so the potential investors can evaluate the financial situation of the company where they want to invest. Beside the fact that financial reports disclosure is imposed by law, companies have the need to generate financial or non financial reports for their activities. Asset management is a program that facilitates the process of invested capital value reporting. Furthermore, nowadays companies are using the ERP (Enterprise Recourse Program), which can integrate the documents of one or more departments in a company. Computer network is developing with giant steps and is helping the business activities every day more.

In this study we want to get to the conclusion that information technology development takes forward the economic thinking. Finance's demands to IT specialists for more detailed, computerized information and how the economic thinking are principal for the information technology developments are the core materials for his study.

To achieve our objective we examine as a case study a company that operates in our country. In the first part we examine the actual reporting level and how the financial data are processed. Then, we take the reporting sheets and the data processing in a higher level of analyzing

This study will be based in academic studies of some authors, legislation and regularity policies in force in our country, corporate government guides and the authors' experience. At the end we will come to some conclusions and recommendations. 


\section{The Importance of Financial Reporting}

Financial reporting is part of the board of directors' responsibility and the shareholders right to be informed for the financial situation [1]. The financial disclosure must be very clear to understand and must present fairly the financial and operational situation of the business activity. This remark is part of almost all corporate governance codes around the world, including OECD, ISGN, and CACG guidelines [2].

The quality of financial disclosure depends on the standards that are applied in the country where the entity operates. Over the last years are applied the International Financial Reporting Standards (IFRS) that make possible the unification of the reporting disclosure around the world [3].

Nowadays several companies, almost all of them, have computer systems. They gather and manage a high quantity of information in these systems. Reporting quality depends on the computer system quality.

Information technology has been developed with giant steps when it comes to financial reporting software. Nowadays, there is nothing that cannot be processed through a computer program. The data can be processed and managed through a computer program that is conceived for a specific reporting disclosure. We can create the balance sheet, revenue and expenses sheet, manage the human recourses or manage the assets.

It is important for these systems to be very confidential and uncorrupted. So, beside the data manipulation, the system should not allow unauthorized entities to interfere on it.

It is the board of directors' responsibility to identify, document and test the information technology controls. If the board doesn't have the technical capacities it is necessary to manage them by the IT Director, who collaborates strictly with the highest managing levels [4]. Information technology has had a key role in the accounting process [5] and in addition the information technology permits the accountant to process several data by using specific queries [6].

At the '60's the accountant was seen as a bookkeeper whose main responsibility was to keep the records. He was responsible for the financial reporting assuring that the information was correct. When the computer and information science were born, information recording became easier and faster. Today the accounting responsibilities are not only on the recording and reporting.

As their job has been easier with the years, an accountant can take forward his thinking by making evident the financial problems and can propose different ways to improve the situation.

The following diagram explains the relation between departments and the importance of their relation in the overall performance [7]



Diagram 1. The process of financial reporting by making use of information technology

But, how far the information technology can go in the financial reporting development? How necessary and important this process is?

This study aims to answer the above questions by making use of a concrete case study.

\section{Pay TV Platforms in Albania}

Pay TV platforms are private companies, which offer for a certain price various television channels in a single package. They do not offer only television channels but technology as well. The television package contains programs, productions, and interactive services, all through an encoded digital transmission.

In Europe the first companies date at years ' 80 , while in Albania the first platform, not with its own production, was created on year 2003, which offered only sports program. At 2004, the first genuine company begins its activity, which 
offered its own production by payment. This company named Digitalb sha. has its activity still going on nowadays and is a leader in the Albanian market. At 2008 another company named Tring TV joins the market and it is facing market consolidation too.

Beside television services offered by both companies, Digitalb sha for being more competitive offers in its package other services as:

- $\quad$ PPV (Pay Per View)-the subscriber pays only for the desired program

- $\quad$ HD (High Definition)- high quality television transmission. This is offered in some of its own channels and in other international channels.

- $\quad$ VoD (Video on Demand, on testing process)- the subscriber will have a library with a wide programming range and can choose anytime the desired program by paying a fee.

Home companies have expanded their target market by offering their services in the region countries as Kosovo, Macedonia, Montenegro, Greece and Europe.

First, Digitalb platform begun with 35 channels in earth transmission and 50 in satellite. Nowadays, this platform has as its content 40 channels in earth transmission and 57 in satellite. In particular, 20 of these channels are programmed by the platform. The Programming Department chooses the content of these channels and manages the timelines. In 2007 the platform successfully transmitted in High Definition in satellite transmission. First, 4 of its selfprogramming channels were transmitted in HD, nowadays there are 6 of them. The company commits to offer this quality even in earth transmission during current year [8].

In 2009, Digitalb tried new ways of transmissions and inc collaboration with some other well-known companies made possible to offer the cable and internet transmission. Nowadays, some efforts are made toward IP-TV but everything is on testing process.

Some of the interactive services are radio channels, teletext, programming guide, English subtitles, Albanian language programming and 18 hours a day help desk.

in 2010, this platform declared to have more than 550,000 subscribers, divided as follows [9]:

- In Albania-390,000 Subscribers, diveded in:

- $42 \%$ earth transmission

- $58 \%$ satellite transmission

- Subscriptions through satellite transmission in Europe:

- 44,000 In Kosovo

- 14,000 In Macedonia

- 12,000 In Montenegro

- 20,000 rest of Europe

- Subscriptions through cable service:

- 24,000 in Kosovo

In 2010 , the sales revenues were of $30,470,000$ Euros with a net profit of $3.4 \%$.

\section{Financial Reporting on Revenues}

Based on the National Accounting Standards 8 (SKK8), revenues are the gross economic benefits, in an accounting period, that derive from the normal activities of an economic entity. These economic benefits increase the capital growth. The main recourse of the revenues is the goods and service sales. In particular, the standard regulates the revenue accounting when the sale happens in a certain moment, but it gets realized in the long run [10].

This process is standardized by the completed phase method [11] or commonly known as the deferred revenues process under which the benefited revenues derived by doing some expenses will be known depending on the period when the service is done in relation of the reporting day with the only condition that the action result must be measured with high credibility. Meaning, on the reporting day, will be recorded only that part of the revenue that belongs to the reported period. This can be measured as a report of the past periods from the purchase date with the total periods when the service is offered. It is necessary to understand the described method so it will be easy to analyze the following financial report.

We have taken on survey one of the home companies that offer pay TV service. The client or the subscriber once purchased the offered goods has the right to access the television channels part of the platform. The subscription period can be short run of a month or long run of 3 and 12 months. The goods can be distributed with two ways:

- $\quad$ Direct sales. This is realized in the shops owned by the company 
- Indirect sales. This is realized by the distributors, other companies that purchase the goods for reselling purposes.

In both ways the offered service is represented physically by a scratch card that contains a hidden code. Once the subscriber wants to activate the service must make use of this code. So the subscriber, or the client, can buy the product in a certain period but can make use of the service in another time when he wants to. There are two moments that are financially significant for the company:

- The product is sold in moment $A$ (when funds are received)

- The service is activated in moment $B$ (the client can access the service by activating the code)

NAS 8 regulates revenues derived by the purchased goods that will be taken into account once that the service is activated (moment B). This may not be a problem if there are few records, but imagine how hard the process of the revenue deferring would become for every activated service for every purchased product in different periods of time! Add to this the historical price matching process with every activated service. Matching these two moments is very frustrating for the accounting.

We will describe the financial reporting of the deferred revenues in a case study by making use of an example. Please take in consideration that the values are fictive and doesn't affect the conclusions.

The client (either final subscriber or distributor) purchase a 12 months subscription card on 01.02.2012 with a given price of 12,000 All. The card is scratched and the service is activated on 03.03.2012. The company report is balance sheet on 31.12.2012. Based on the national standard the company must record as its revenue for the sold product only a proportion of the revenue which equals the part of the paid price. This part is the proportion of the period in which the subscriber has profited from the activating day until the reporting day.

This process is realized by the help of Excel software, part of Microsoft Office.

\begin{tabular}{|c|c|c|c|c|c|c|}
\hline Purchasing day & Price & Activating day & Reporting day & Service days & Service proportion & Reported revenue value \\
\hline$(\mathrm{A})$ & $(\mathrm{X})$ & $(\mathrm{B})$ & $(\mathrm{C})$ & $(\mathrm{D})=(\mathrm{C}-\mathrm{B})$ & $(\mathrm{E})=(\mathrm{D}) / 365$ & $(\mathrm{ExX})$ \\
\hline $2 / 1 / 2012$ & $12,000.00$ & $3 / 3 / 2012$ & $12 / 31 / 2012$ & 305 & 0.84 & $10,027.40$ \\
\hline
\end{tabular}

Table 1. Calculation of deferred revenues by Excel

The sum of the values of the last column is the value that must be taken into account for the balance sheet as the revenue value for the reported period.

All the information that is shown in the first three columns is taken from the software that is on the company's property. The software is functionally managed by Information Technology Department. All the information is recorded by some sectors of various departments of the company depending on their functions.

The first data recording is done by the Sales Department, Activation Sector, when the sales invoices are registered. In this moment are recorded some data of the "Moment A" like the sold price, the card number, the purchased date, the client's name or the distributor account is debited.

The software can automatically generate some financial reporting on the distributor's financial account. The report consents all the products that a distributor has purchased, how much has been paid and how much is to be received. For as long as these reports are automatically generated they will not be subject of our analysis.

\begin{tabular}{|c|c|c|c|c|c|c|c|c|}
\hline Data & Distributori & Produkti & Tipi & Sasia & $\begin{array}{r}\text { Cmimi } \\
\text { Final }\end{array}$ & $\begin{array}{l}\text { Cmimi } \\
\text { Distrib. }\end{array}$ & Totali & Shenime \\
\hline $11 / 01 / 2013$ & A ship.k & Karte Abonimi & Dalje & 20 & & & L & \\
\hline $11 / 01 / 2013$ & sh,p.k & Karte Abonimi & Dalje & 50 & & & L & \\
\hline $11 / 01 / 2013$ & sh.p.k & $\begin{array}{l}\text { Karte Abonimi } \\
\text { Premium }\end{array}$ & Dalje & 10 & & & L & \\
\hline
\end{tabular}

Fig 2. Financial report generated from the actual software

In the system it is automatically recorded the date and the hour when a purchased card has been scratched and activated by the subscriber by using a short code message service (SMS). The program shows the needed data by making use of some filter criteria and can match the activated card with its sold price (moment A and B shown in the first three columns 
of the table 1).

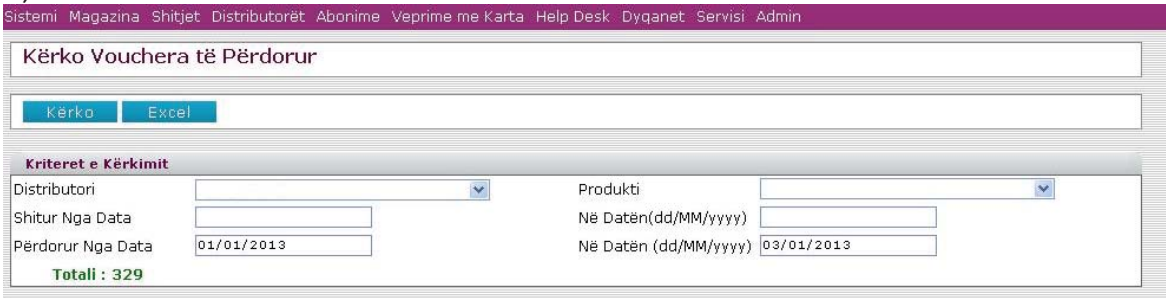

Fig 3. Filtering the needed data shown in Table 1

Preparing the table may seem a simple procedure at first sight, but if we take in consideration the large amount of the activated cards during a reported period it becomes really hard to compile it in the right way. The process is long and some problems arise:

- the data processing may lead to human mistakes

- it takes a long time to process

- the process needs high knowledge of the computer programs

- Excel program doesn't allow to import a large amount of data (I.e. In Excel 2003 maximum numbers of rows is $65,536)$

For this reasons we come to the conclusion that due to the importance of the exact reported value it is not efficient and not productive when it comes to the quality of using the working hours by the specialist, in charge of preparing this table among other functions. In this moment our thinking must go deeper to find an efficient solution. It is necessary and highly recommended for this report to be automatically generated from the actual software. For this, there must be a close relation between Finance Department and Information Technology so the IT may have a clear situation of the requests and the final product.

From the beginning of this study until now some efforts are done toward the automatically report generation. This has been possible by the collaboration of both departments. Actually the report is in testing process and some advantages are already seen:

- elimination of human mistakes

- report can be generated in real time (every moment it is asked by the shareholders)

- productivity at work increased by $20 \%$

- Information Technology interest increase toward the requests of Financial Department for other automatically report generation process

This case study doesn't aim to give a solution to a concrete example, but to make evident the important relation between economists and information technology and vice versa. This relation and teamwork can lead to progress not only to information technology but also to economic thinking when it comes to financial reporting.

\section{Economic Thinking Development}

The most important challenge of an entity is its activity forecast in the future. How can the future be predicted under risk and uncertain terms? The answer is by analyzing the past financial information and studying the economic growth of the country where the activity occurs. We will analyze how the information of the past years activity can be processed to forecast the future when all other factors are ceteris paribus.

To predict the revenues that a company will have an economist must have as core information the sales forecast. Cash budgeting is a well-known concept in finance. By forecasting the future cash inflows and outflows the company can predict its ability to invest in new projects.

Cash flow budgeting in a pay television is based first in the following forecasts:

- cash inflows from its trading activity

- advertising revenues

- licenses to other local televisions that use the platform's channels etc.

We will study how the company may forecast the revenues that may occur by selling the subscription cards.

The company offers subscriptions with a validity of 1,3 , or 12 months. The subscriber may buy the card when he 
has the funds but he uses the service when he needs it. We already know that the company has the software that can give the information when the card is sold and when it has been used. The company is interested to know how many subscribers will renew their subscription this year, so the entity can forecast its cash inflows. Analysis begins once we have in hand the information of the past years subscriptions for each month.

The following material analyses the statistical methodology that can be used to calculate the probability for each month that a client can subscribe for the budgeting year once we have the last years' data. We have taken in consideration only two months as past data but the example can be used even if we have the information of more than one year. The information actually is processed through Excel software.

The following numbers are fictive as we are not interesting in the case study but in the methodology used in predicting the future and how the information is processed.

\begin{tabular}{|c|c|c|c|c|c|}
\hline \multirow[t]{2}{*}{ Period } & \multirow{2}{*}{$\begin{array}{c}\text { Subscription card } \\
\text { period }\end{array}$} & \multirow{2}{*}{$\begin{array}{c}\text { Activated } \\
\text { cards number }\end{array}$} & Number of Smart cards & \multirow{2}{*}{$\begin{array}{l}\text { Total capacity (number of } \\
\text { cards } \\
\text { for each type of cards) }\end{array}$} & \multirow{2}{*}{$\begin{array}{l}\text { Probability } \\
\text { of } 1 \text { month } \\
\text { subscription }\end{array}$} \\
\hline & & & $\begin{array}{c}\text { (potential clients } \\
\text { number) }\end{array}$ & & \\
\hline \multirow{3}{*}{ January } & 1 month & 12000 & \multirow{3}{*}{40000} & 720000 & 0.04 \\
\hline & 3 months & 10000 & & 240000 & 0.13 \\
\hline & 12 Months & 8000 & & 60000 & 0.13 \\
\hline \multirow{4}{*}{ February } & 1 month & 7800 & \multirow{3}{*}{60000} & 720000 & 0.01 \\
\hline & 3 months & 9500 & & 240000 & 0.04 \\
\hline & 12 Months & 6000 & & 60000 & 0.10 \\
\hline & \multicolumn{4}{|c|}{ Subscription probability (odds that potential clients activates the service) } & 0.4504 \\
\hline
\end{tabular}

Table 2. Calculating the probabilities of future subscriptions

Data processing by a specialist has its own disadvantages and problems:

- human errors may occur

- requires a lot of data exporting from the actual software to Excel

- inefficient working hours for the specialist

For these reasons it is necessary for finance and information technology to collaborate in the near future to achieve the final report directly from the program. This may be done either by the entity's capacity in information technology or by another specialized company.

The following achievements will arise:

- a better forecast of the future subscriptions number

- results may be processed in real time

- a better prediction of future revenues/cash inflows

- other factors that can influence the results can be used in the probability analysis methodology

- efficient working hours for the specialist

Another methodology of predicting the revenues is the time series analyze by making use of the trend [12]. First the specialist must have the monthly sales of the past long-life period. These data can be taken at the program by using some filters at the reports section.

The data can be exported to Excel content of the Microsoft Office package. By processing the information the specialist can have a chart diagram and predict the future sales.

For the above reasons this method is not efficient for the data processing. There must be collaboration between both departments in order to realize the report directly from the program.

In the following is described the methodology for the data processing and calculating the trend value.

Trend-line equation: $T_{5}=b_{0}+b_{2} t$

Whereas: $T_{t}=$ trend value of a time series in period $\mathrm{t}$

$b_{\mathbf{Q}}=$ ordinate in the origin of the trend-line

$b_{1}=$ slope coefficient of the trend-line

$\mathrm{t}=$ time

Calculating $b_{0}$ and $b_{1}$ : 


$$
b_{0}=\frac{n \sum t Y_{t}-\left(\sum t \Sigma\left[Y_{t}\right)\right]}{n \sum t^{2}-\left(\sum I t\right)_{2}^{2}} \quad B_{0}=\bar{Y}-b_{2} \bar{t}
$$

Whereas: $Y_{t}=$ time series value in period $\mathrm{t}$

$\mathrm{n}=$ periods number

$\bar{Y}=$ time series values average

$\bar{E}_{=}$t's average

The above case studies have analyzed the advantages of the automatically data processing for the purpose of improving financial disclosure and future forecasting that are important for managerial decisions.

We precede further on our study by suggesting that the program, actually used by the company, both because it already generates some financial reports, and as it manages the main database, can be used for more complicated reports and become the main reporting software. Besides, we suggest making possible the program access from mobile devices. We find some advantages in using this model:

- highest managerial levels can have general and specific information of the financial situation every moment

- highest managerial levels can have general and specific information of the financial situation every place

We must emphasize that this approach must be followed by rigorous security measures as long as the information is confidential and very important.

So far we have analyzed several reports that a company can and need to generate for having total financial information in its hands. Companies may have the need to gather information from its branches or distributors. We will continue our study on giving a real case of how a company can gather the needed data from all its branches and process them in one database. The new technologies offer to us a Cloud database to achieve this goal.

Coming back to our case study, the company needs to have everyday information from all its distributors. A list of needs is shown below:

- a map of all the shops where the entity and distributors operate

- everyday sales in all the shops

- everyday final clients requests/claims on the offered service

- everyday number of clients that enter the shop and buy/do not buy

The gathered information can be accessed and used from:

- marketing department to process the clients requests and improve the services

- sales department to process the sales developments and forecast the future

- finance department to forecast the future cash inflows

- managerial levels to take strategic policies that regard the services and overall management

The above needs bring us to a specific business scenario.

\section{A Business Scenario}

Business specifics provoke different scenarios about the organization of the information. Related with what we mentioned above about the distributors, our business is composed by some branches in different locations and a need of the business is the centralization of the reports of each branch. The information of the central database would be used by all branches. Therefore a local database would be appropriate for each branch and in the same time there is a central database where the data would be available for all the branches. The Cloud Computing technology is a facility today that makes this idea a concrete reality in a very simple way. The approach presented in this article is an alternative that aims exactly this goal.

Considering Google Cloud platform and the services offered by Google API the scenario can be implemented integrating some components. One of them is Google Cloud SQL [13], which makes possible to create and use a cloud database as the central database mentioned above. There would be too many advantages to organize this central database in a Cloud Platform, like: easy to use, fully managed, highly available, exceptional security, etc. Google Cloud SQL offers the capabilities of a MySQL database, and the maximum of the storage that it is provided by this platform is 100GB of data storage.

The other component would be a web application that makes the connection and management of the cloud database with the client. Different alternatives can be used and Google App Engine is one of them. [14]

The technology extends our idea. We would like to use of the central database from any place and at any time. 
In this case another important component should be included in this approach and this is an application in a small device, like smart-phones. An Android application would activate the web application and this everybody would have the opportunity to use the database information at any time, at any place.

A close cooperation of the financial and IT department that would make this approach a reality.

\section{Conclusions}

In this study we analyzed an experience of the company Digitalb Sha. about the accounting and finance duties and some ideas that this experience brings in the future work of a business.

Information technology is a big helper today in every field and especially in the accounting and finance field. Specific businesses have their own software-s, but never the software is able to fulfill all the needs that a business has. This is a natural phenomena because the requirements of a business are allays in development process, which is dictated by the concurrence laws.

This process of the personalization of the software is a continuous cooperation between Information Technology department of the company and the financial one. Who is the leader in this cooperation? They lead each other alternatively. The business people use the software and the features that the software offers make them to understand better what they need and what it is possible to be added as new features in this software.

The new technologies and the fact that all the people are informed today about their existence by the Internet has increased the conscience and imagination of the people for a higher level of their work.

The Cloud Computing integration in their work is an innovation for the businesses today. The implementation of the idea of a Cloud central database, where information of all its branches can be gathered would bring a higher work performance in a company with a similar business scenario.

The use of the small devices in the business activity is another idea closely linked with the Cloud Computing technology, which will bring evolution in the business activity.

\section{References}

United Nations Publication (2006) "Guidance on good practices in corporate governance disclosure" New York and Geneva, ISBN 92-1112704-1

http://www.deloitte.com/view/en_CA/ca/services/ceocfocertification/2b21cb79791fb110VgnVCM100000ba42f00aRCRD.htm

Céu Gaspar A. Maria (2010) "Information Technology roles in Accounting Tasks - A Multiple-case Study" International

Journal of Trade, Economics and Finance, Vol. 1, No. 1, June, 2010

Congress, Office of Technology Assessment, OTA-CIT-202, September 1984

D. Jason, G. Vijay, L. K. Keneth "Information Technology and Economic performance: A Critical Review of the

Empirical Evidence" University of California, Irvine ACM Computing Surveys, Vol. 35, No. 1, March 2003, pp. 1-28.

Deloitte (2005) "Why information technology controls can't be ignored CEO/CFO" Certification News May 2005

www.digitalb.al

Binjaku, A. (2011) "Analiza e efektivitetit ekonomik dhe financiar e sektorit televiziv me pagese" Mikroteze Universiteti Europian I Tiranes

Standardi kombëtar i kontabilitetit nr. 8 "Te ardhurat" miratuar nga Këshilli Kombëtar i Kontabilitetit dhe shpallur nga Ministria e Financave

Binjaku, H. Binjaku, A. (2012) "Ushtrime të zgjidhura Statistika 1 dhe 2"

Google Cloud SQL 2013 https://developers.google.com/cloud-SQL/

https://developers.google.com/eclipse/docs/cloudSQL-createapp

www.tring.al

https://developers.google.com/eclipse/

http://www.minfin.gov.al/minfin/pub/skk_08_te_ardhurat_3039_1.pdf

"Effects of Information Technology on Financial Services Systems' (Washington, D. C.: U.S.)

H. Jacob, M. Adi, J. R. Vernon, Manuel S. Juan (2011) "The Impact of Information Technology Material Weaknesses on Corporate Governance: Evidence from Executive and Director Turnover, and IT Governance Changes" University of Arkansas

Xhafa, H., (2005). "Analiza e pasqyrave financiare". 